\title{
Recognition and reanalysis of a cell line from a manifesting female with X linked hypohidrotic ectodermal dysplasia and an X;autosome balanced translocation
}

\author{
JONATHAN ZONANA*†, SELWYN H ROBERTS*, \\ NICHOLAS S T THOMAS*, AND PETER S HARPER* \\ From ${ }^{*}$ the Institute of Medical Genetics, University of Wales College of Medicine, Heath Park, Cardiff CF4 \\ $4 X N$; and †Department of Medical Genetics and Crippled Children's Division, Oregon Health Sciences \\ University, Eugene, Oregon 97403, USA.
}

SUMMARY We have restudied a fibroblast cell line from a female with marked manifestations of $X$ linked hypohidrotic ectodermal dysplasia (HED) and a balanced X;9 translocation. Chromosome analysis showed a karyotype of $46, X, t(X ; 9)(q 13 \cdot 1 ; p 24)$ with an $X q$ breakpoint distal to the one previously reported. The significance of the cell line, previously unrecognised, for the mapping and eventual cloning of the HED locus is discussed.

The identification of females with $\mathrm{X}$;autosome balanced translocations and marked manifestations of $\mathrm{X}$ linked disorders has assumed increasing importance over the past few years. It has become evident, as in the case of Duchenne muscular dystrophy (DMD), that such rare patients may not only supply a vital clue to the detailed localisation of the disorder, but in addition may assist in the actual cloning of the gene locus itself. ${ }^{12}$ It has recently been shown in DMD that the females with manifestations of the disorder have the breakpoints of their translocations within the disease locus. ${ }^{3}$ This is consistent with the theory that such translocations disrupt one normal allele in the formation of the derivative chromosomes and, with the usual preferential inactivation of the normal $X$ chromosome in balanced $\mathrm{X}$; autosome translocations, produces a phenotype similar to that of an affected hemizygous miale.

Several groups have been involved in the regional mapping of the $\mathrm{X}$ linked disorder hypohidrotic ectodermal dysplasia. ${ }^{4-6}$ We have recently found, through linkage studies using restriction fragment length polymorphisms in 36 families, very close linkage of the disorder to three pericentromeric marker loci (DXS159, PGK1, and DXS72) physically localised to the Xq11-q21.1 region. ${ }^{7}$ However, we have been unable to order the disease and

Received for publication 18 November 1987.

Revised version accepted for publication 18 December 1987. marker loci because of a relatively limited degree of genetic recombination between the loci in the pericentromeric region. The fine subregional localisation of the disorder will depend on physical mapping of the disorder, assisted by the study of either affected males with cytogenetic or molecular deletions (none identified to date), or of manifesting females with $\mathrm{X}$;autosome balanced translocations.

The sole $\mathrm{X}$; autosome balanced translocation with manifestations of HED known to exist is a patient verbally reported at the first Human Gene Mapping Conference (1974) by the late Dr Peter Cook from the United Kingdom. The only published confirmation of this fact is in a footnote to the proceedings of the conference, but no clinical description of the patient was provided. ${ }^{8}$ The patient had been previously studied in the United States by Cohen et al, ${ }^{9}$ ascertained at the age of six months because of failure to thrive without recognition of her manifestations of HED. She was reported as part of a study of the patterns of $\mathrm{X}$ chromosome inactivation in $\mathrm{X}$; autosome translocations, with a karyotype of $46, \mathrm{X}, \mathrm{t}(9 \mathrm{p}+; \mathrm{Xq}-)$.

Attempts have been made by our group and others to trace this patient, apparently lost to follow up, in order to establish a cell line for molecular studies, both for gene mapping purposes and for the eventual cloning of the gene itself. We wish to report the 'rediscovery' of a fibroblast cell line from this patient, to present relatively high resolu- 
tion chromosome studies, and to draw attention to extremely useful published somatic cell gene mapping studies, which have used hybrids constructed from this cell line.

\section{Methods}

CYTOGENETIC ANALYSIS

Cytogenetic studies were undertaken on a fibroblast culture obtained from the NIGMS Human Genetic Cell Repository (GM0705), ${ }^{10}$ established from the patient originally described by Cohen et al. ${ }^{9}$ This cell line is also referred to as the AnLy line. Chromosome preparations were obtained using conventional techniques except that exposure to colcemid was restricted to 30 minutes in order to obtain chromosomes suitable for high resolution studies. GTG banding was accomplished using a modification of the method of Seabright. ${ }^{11}$ Late replication studies were performed using a modification of the method of Perry and Wolff, ${ }^{12}$ whereby BrdU (final concentration $100 \mu \mathrm{g} / \mathrm{ml}$ ) was added for the last five hours of culture. Slides were stained in Hoechst $33258(10 \mu \mathrm{g} / \mathrm{ml}$ deionised water $)$, exposed to ultraviolet light for 15 minutes, and incubated in $2 \times \mathrm{SSC}$ at $60^{\circ} \mathrm{C}$ for five minutes, before staining in $10 \%$ Giemsa.

\section{Results}

CYTOGENETIC STUDIES

Examination of the $G$ banded preparations confirmed the presence of an $X ; 9$ balanced translocation. The breakpoints were at the junction of bands $\mathrm{Xq} 12$ and $\mathrm{Xq} 13 \cdot 1$, or in the proximal region of Xq13.1 and at band 9p24, respectively (figs 1 and 2). There appears to be no reduction in the width of band $\mathrm{Xq} 12$ on the derivative $\mathrm{X}$ chromosome, nor is any dark band apparent at the junction of $\mathrm{X}$ and 9 chromosomal material on the derivative 9 . The karyotype, according to conventional nomenclature, ${ }^{13}$ was thus designated: $46, \mathrm{X}, \mathrm{t}(\mathrm{X} ; 9)(\mathrm{Xpter} \rightarrow$ $\mathrm{Xq13} \cdot 1:: 9 \mathrm{p} 24 \rightarrow$ pter;9qter $\rightarrow$ 9p24::Xq13·1 $\rightarrow$ Xqter $)$. RBG banding showed the normal $X$ chromosome to be late replicating in each of the 28 divisions examined. There was no evidence of late replication of either of the translocation products.

\section{Discussion}

The early clinical history of the patient initially reported by Cohen et al $t^{y}$ is consistent with the type of clinical problems encountered in male infants with HED. ${ }^{4}$ During the first six months of life, she had frequent respiratory tract infections, feeding problems requiring a gastrostomy, and an unusual

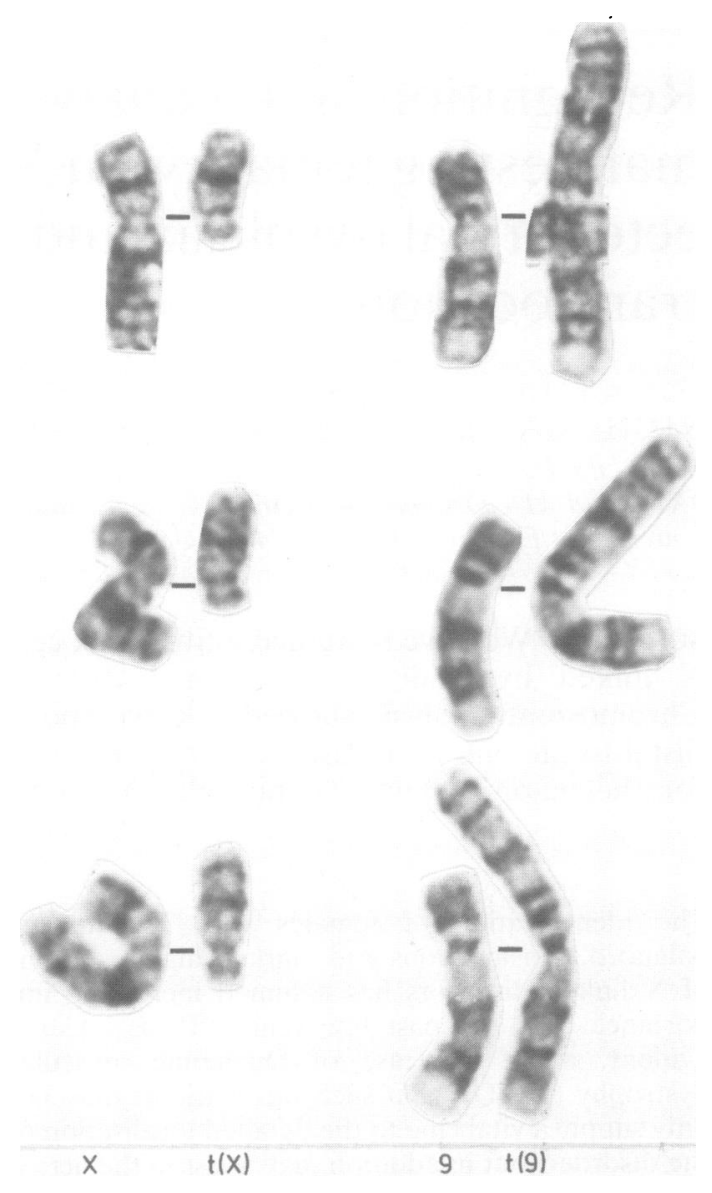

FIG 1 GTG banded partial karyotypes from three cells showing the products of the balanced translocation $t(X ; 9)(q 13 \cdot I ; p 24)$ and the normal homologous chromosomes.

facial appearance with frontal bossing and fine, sparse hair. It is not surprising that the correct diagnosis was not made at the time, since the diagnosis is frequently delayed in male infants when they are sporadic cases. Chromosome studies on her parents and sibs were normal. Recently, the past medical and dental records (including photographs) from the patient's childhood in the United Kingdom have been reviewed (K MacDermot, 1987, personal communication), and they confirm Cook's original observations of a female with marked manifestations of hypohidrotic ectodermal dysplasia.

Recently, one of the authors (JZ) noted, while reviewing the proceedings of the first Human Gene Mapping meeting, a report by Shows and Brown ${ }^{15}$ 


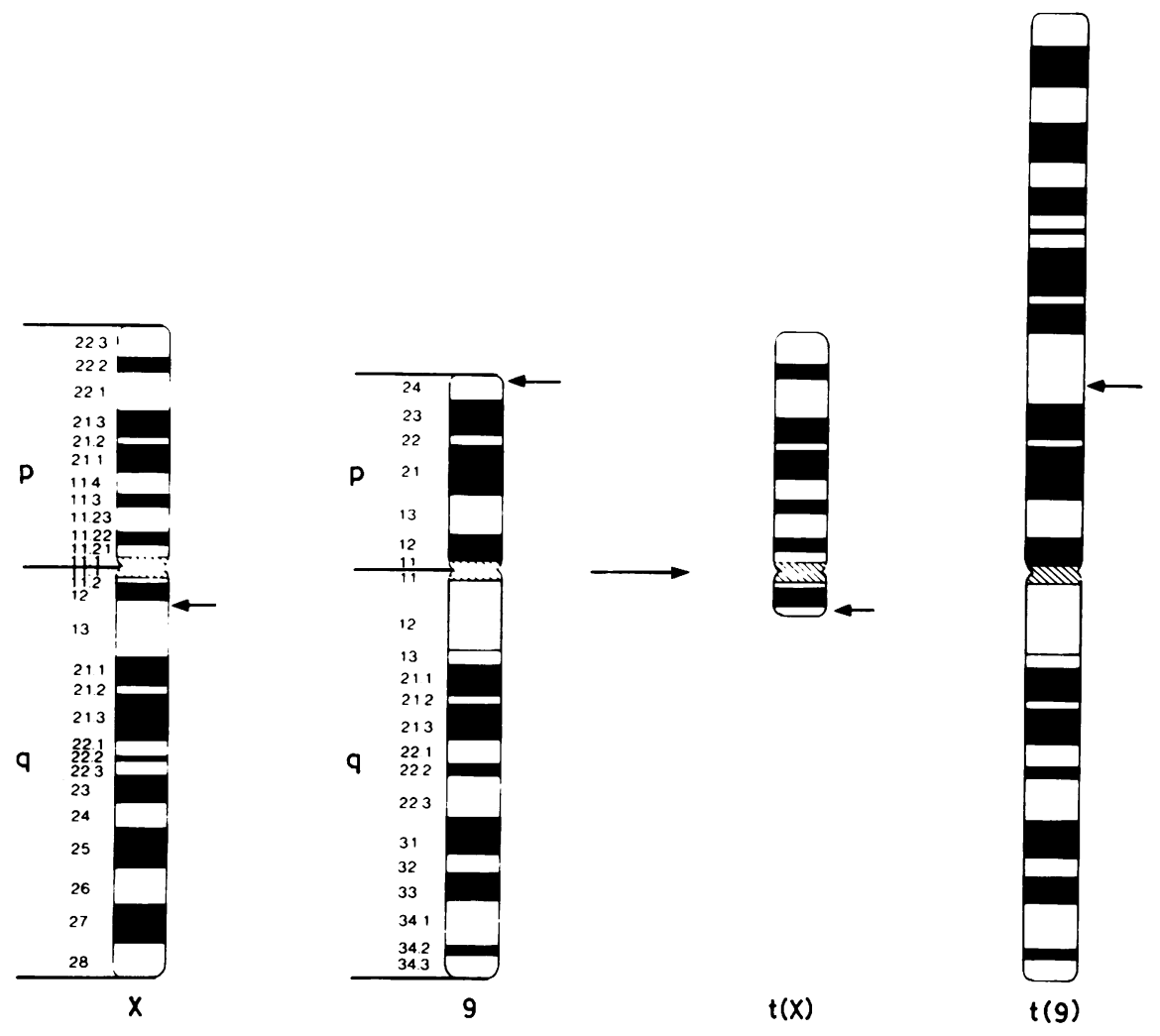

FIG 2 Diagram of the $t(X ; 9)(q 13 \cdot 1 ; p 24)$ translocation showing the breakpoints (arrows) in the normal chromosomes and the translocation products.

on the localisation of several gene loci to the long arm of the $\mathrm{X}$ chromosome by the then relatively new method of somatic cell hybrid mapping. In this study, they constructed hybrid lines from the patient previously reported by Cohen et al..$^{9}$ A check of the catalogue from the NIGMS Human Genetic Cell Respository showed that $\mathbf{J}$ A Brown had deposited a fibroblast line from this patient in 1974. The only clinical description of the patient listed by the repository (to the present day) is "failure to thrive". ${ }^{10}$ The first two letters of the first and last names of the patient from whom the cell line was established (AnLy) are identical to those of the patient originally diagnosed as having HED by Cook. In addition, the UK hospital records of this patient reiterate the patient's previous admissions to hospital and evaluations reported by Cohen et al 9 (K MacDermot, 1987, personal communication). These observations confirm that the AnLy cell line is from a female with severe manifestations of $X$ linked hypohidrotic ectodermal dysplasia.
Shows and Brown ${ }^{15}{ }^{16}$ originally placed the breakpoint of the translocation at the junction of the Xq11 and $\mathrm{Xq} 12$ bands, describing the karyotype as $46, \mathrm{X}, \mathrm{t}(\mathrm{Xq}-; 9 \mathrm{p}+)(\mathrm{q} 12 ; \mathrm{p} 24)$. Our reanalysis of the cell line, with higher resolution chromosome studies, defines a slightly more distal breakpoint, at the junction of the Xq12 and Xq13.1 bands, or in the proximal region of $X q 13 \cdot 1$. We confirmed the earlier finding (as expected) of inactivation of the normal $\mathrm{X}$ chromosome in all cells examined, but did not observe evidence of additional late replication of the $\mathrm{Xq}$ portion of the derivative chromosome 9 , as initially reported by Cohen et at in $32 \%$ of cells.

A number of investigators have continued to use the AnLy cell line, without apparent recognition of the patient's true phenotype, in the construction of somatic cell hybrids to localise both expressed genes and anonymous DNA marker loci. ${ }^{17-20}$ The wide use of somatic cell hybrids, derived from the AnLy line, by several groups physically mapping the pericentromeric region of the $\mathrm{X}$ chromosome, pro- 
vides us with useful information on placing loci either proximal or distal to the translocation breakpoint.

Under the assumptions that the AnLy translocation physically disrupts the HED locus, and that there have not been any significant rearrangements in the somatic cell lines, we are now able to propose the order cen-DXS159-HED-PGK1-DXS72 for HED and the tightly linked DNA marker loci. ${ }^{7}$ For example, we have found close linkage of $H E D$ and the $P G K 1$ locus $(\theta \max =0 \cdot 02)$, but were unable to order the loci by multipoint analysis. However, two groups have localised the $P G K 1$ locus distal to the AnLy breakpoint; thus we would place the $H E D$ locus proximal to the $P G K 1$ locus. ${ }^{15} 17$ Similarly, Arveiler et $a l^{20}$ have mapped the DXS159 locus proximal to and DXS72 distal to the AnLy breakpoint. The ability to determine flanking markers is of crucial importance in the clinical application of linkage data for both carrier detection and prenatal diagnosis of $\mathrm{X}$ linked hypohidrotic ectodermal dysplasia.

The recognition of the full significance of the AnLy cell line should provide further opportunities for molecular studies. The location of the marker loci in relation to the translocation breakpoint, previously established by somatic cell studies, can be confirmed by in situ hybridisation studies on the fibroblast line, eliminating the problem of possible de novo chromosomal rearrangements in the somatic cell hybrids. Finally, although no simple task, the possibility now exists of isolating the junctional fragments from the derivative chromosomes, identifying RNA transcripts from these clones, and ultimately discovering the gene product necessary for normal ectodermal morphogenesis.

We are most grateful to Dr R F Wheater for his technical assistance and advice.

\section{References}

' Boyd Y, Buckle V, Holt S, Munro E, Hunter D, Craig I. Muscular dystrophy in girls with $\mathrm{X}$;autosome translocations. J Med Genet 1986;23:484-90.

2 Ray PN. Belfall B, Duff C, et al. Cloning of the breakpoint of an $\mathrm{X} ; 21$ translocation associated with Duchenne muscular dystrophy. Nature 1985;318:672-5.

${ }^{3}$ Kocnig M, Hoffman EP, Bertelson CJ, Monaco AP, Feener C, Kunkel LM. Complete cloning of the Duchenne muscular dystrophy (DMD) cDNA and preliminary genomic organization of the DMD gene in normal and affected individuals. Cell 1987:50:509-17.
${ }^{4}$ MacDermot KD, Winter RM, Malcolm S. Gene localisation of X-linked hypohidrotic ectodermal dysplasia (C-S-T syndrome) $\stackrel{\text { ? }}{+}$ Hum Genet 1986;74:172-3.

5 Kolvraa S, Kruse T, Jensen PKA, Linde KH, Vestergaard SR등 Bolund $\mathrm{L}$. Close linkage between $\mathrm{X}$-linked ectodermal dysplasiक and a cloned DNA sequence detecting a two allele restriction fragment length polymorphism in the region Xp11-q12. Humo Genet 1986;74:284-7.

- Clarke A, Sarfarazi M, Thomas NST, Roberts K, Harper PS. X-linked hypohidrotic ectodermal dysplasia: DNA probe link $\overrightarrow{0}$ age analysis and gene localization. Hum Genet 1987;75:378-80.-

7 Zonana J, Clarke A. Sarfarazi M, et al. X-linked hypohidrotic ectodermal dysplasia: localization within the region Xq11-q21.10 by linkage analysis and implications for carrier detection an prenatal diagnosis. Am J Hum Genet (in press).

8 Gerald PS, Brown JA. Report of the committee on the genetiqu constitution of the $\mathrm{X}$ chromosome. Cytogenet Cell Genefr 1974;13:29-34.

9 Cohen MM, Lin CC, Sybert V, Orecchio EJ. Two human X autosome translocations identified by autoradiography and fluorescence. Am J Hum Genet 1972:24:583-97.

${ }^{10}$ NIGMS. Chromosomally aberrant human fibroblasts (GM0705). Catalog of cell lines. NIGMS Human Genetic Mutant Cell Repository 1986:155.

"Seabright M. A rapid banding technique for human chromo somes. Lancet 1971;ii:971-2.

12 Perry P, Wolff S. New giemsa method for the differentia staining of sister chromatids. Nature 1974;251:156-8.

13 ISCN (1978). An international system for human cytogenetic nomenclature. Birth Defects 1978;XIV:8.

${ }^{14}$ Clarke A, Phillips DIM, Brown R, Harper PS. Clinical aspectš of X-linked hypohidrotic ectodermal dysplasia. Arch Dis Child 1987;62:989-96.

15 Shows TB, Brown JA. An $(\mathrm{Xq}+; 9 \mathrm{p}-)$ translocation suggest the assignment of G6PD. HPRT, and PGK to the long arm o: the $\mathrm{X}$ chromosome in somatic cell hybrids. Cytogenet Cell Genef 1974:13:146-9.

16 Shows TB, Brown JA. Human X-linked genes regionally mapped utilizing $\mathrm{X}$-autosome translocations and somatic celf hybrids. Proc Natl Acad Sci USA 1975;72:2125-9.

17 Grzeschik KH, Siniscalco M. Identification of a de novochromosome rearrangement in a man-mouse hybrid clone and its bearing on the cytological map of the human X chromosome Cytogenet Cell Genet 1976;16:149-56.

is Wieacker P, Davies KE, Cooke HJ, et al. Toward a completelinkage map of the human $\mathrm{X}$ chromosome: regional assignmento of 16 cloned single-copy DNA sequences employing a panel of somatic cell hybrids. Am J Hum Genet 1984;36:265-76.

14 Obcrle I, Camerino G, Kloepfer C, et al. Characterization of a음 set of X-linked sequences and of a panel of somatic cell hybrids useful for the regional mapping of the human $\mathrm{X}$ chromosome Hum Genct 1986;72:43-9.

20) Arve:ler B, Oberle I, Mandel JL. Genetic mapping of nind DNA markers in the q11-q22 region of the human $\mathrm{X}$ chromosome. Genomics 1987;1:60-6.

Correspondence and requests for reprints to Dr Zonana, Crippled Children's Division, University of Oregon, 901 E 18th Street, Eugene, Oregon 97403, $\stackrel{\text { ? }}{?}$ USA. 